\title{
Exegesis of Gen 12: 1-9 as Pattern for Christian Priests
}

\author{
Chisom S. Ugwuewo
}

Department of Religion and Cultural Studies, University of Nigeria, Nigeria

Copyright@2019 by authors, all rights reserved. Authors agree that this article remains permanently open access under the terms of the Creative Commons Attribution License 4.0 International License

\begin{abstract}
Priesthood is associated with religion, Christianity, a type of religion is not an exemption. There are ordained and lay priesthood in today's ecclesiology. In this paper, the researcher employed narrative method of biblical exegesis for proper interpretation of the study text. In the contemporary, the conduct and attitude of priests seem absurd. It has metamorphosed to a degree that priesthood has become religious industry instead of total obeisance to divine call. It is therefore necessary to attempt to ameliorate the undeserved situation the church priesthood has delved into. In order to make this a reality, Old Testament Abram became the choice of study. Abram was chosen by the LORD to abstain from apostasy to monotheistic religion. The following virtues were found in him: obedience, humility, creativity, love, industrious, faith, fidelity, knowledge and so on. The researcher contends that when Abraham's pattern of life style is recommended to teeming Nigerian church priests and applied by them, there would be rejuvenation of both the church and Christian priesthood in Nigeria.
\end{abstract}

Keywords Priesthood, Christian Priest, Pattern, Obedience, Attitude

\section{Introduction}

Priesthood is a sacred office as well as a divine call. It remains one of the most developed institutions in Christianity. It is a very crucial position in the world of Christianity, and this is why Christian priests are regarded as representatives of God in Christian faith. Their roles are well spelt in both the Christian scripture and other sacred traditions of the church. In the modern time, the roles of priests are beyond church services/work; they today work in various places such as schools as teachers, higher institutions of learning as lecturers and non-academic staff, political sector as administrators among others. Some of them are business tycoons, some market traders and some bankers. Some are also engaged in craft handiwork etc. But the researcher in this paper attempts to limit priests to those who take priesthood as only or major occupation.

The text of study in this research is a narrative of Abram's divine call to leave his ancestral home to an unknown land and his subsequent submission to the command without complaint and hesitation. He left his possession in Haran and began to sojourn to a place he did not know not minding his old age and predicament of his wife's barrenness, in order to please the LORD.

Today, corruption and materialism are not detached from contemporary priests. It is elusive to identify moral lifestyle among today's priests. Holiness and righteousness have been replaced with high rate of immorality. Ugwu on this note made it clear that there is negative face of priesthood which includes materialism, non-impacting sermons and teaching, immorality and high-handedness. It is undoubtable that there is a decline in the rectitude of priests as long as Christianity is concerned. Many priests assume the office of priests with ulterior motive of material gain instead of leading Christians the right way to uprightness.[1] Bribery and gerrymandering among priests during posting authenticate this claim. It is a pathetic condition that priesthood which ought to be taken as a sacred office is now taken to be religious industry for money making and accumulation of wealth.

In this paper, the researcher intends to discuss the bastardization of sacredness of priesthood and use the text of Gen 12: 1-9 to suggest way forward. To make this goal a reality, the researcher adopts narrative method of exegesis, because the gattungen (genre) of the text under investigation is a narrative.

\section{The Hebrew Text}

\footnotetext{
tyBeämiW $\wedge$ T.d $>$ l;AM)miW $\wedge$ ïc.r>a;me $\wedge \pm$ l.-\%l, r"êb.a;-la, 'hw"hy> rm,aYOÝw: 1

'\&'a<)r>a; rv<ïa] \#r<a'Ph'-la, ^ybi_a'

'hk'(r"B. hyEßh.w $<\wedge$ m $<+$ v. hl'pD>g:a]w: ^êk.r $<$ b'äa]w: lAdêG" yAgæl. ‘^f.[,a,(w 2

txoïP.v.mi lKoß ^êb. Wkår >b.nIw> rao=a' ^ßl.L,q;m.W ^yk,êr>b"åm. 'hk'r]b")a]w: 3
} 


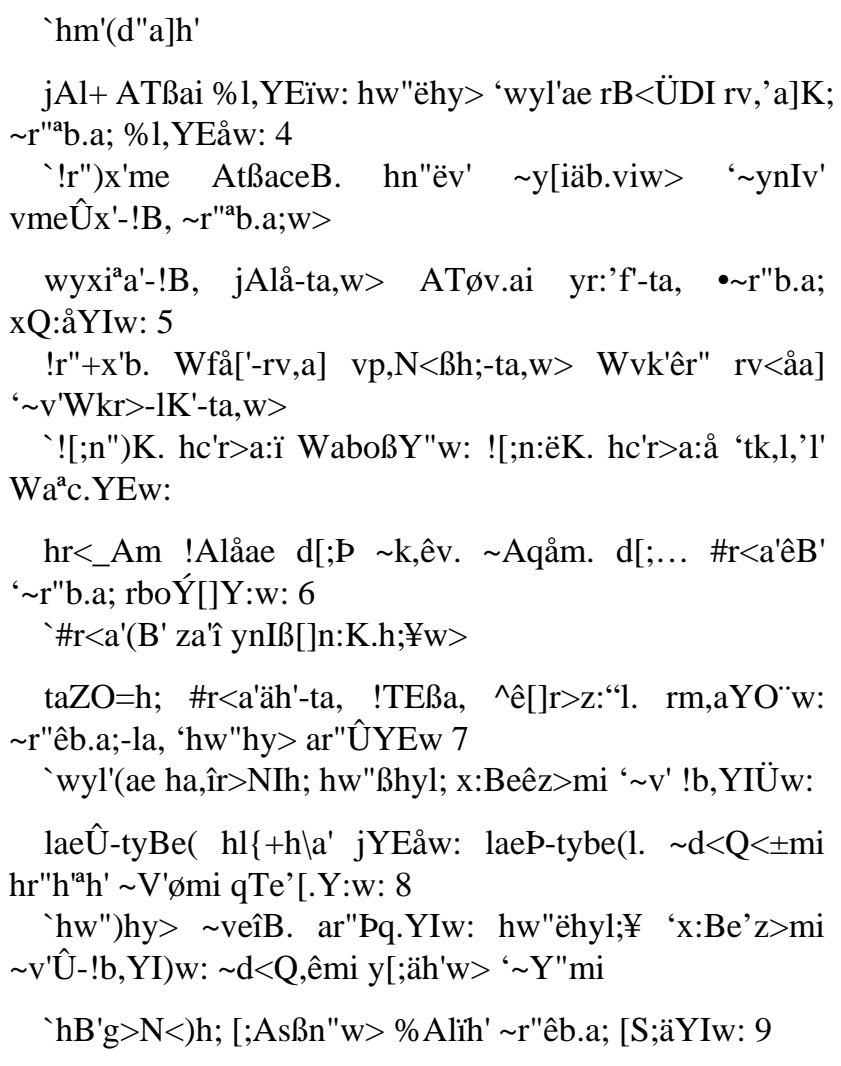

\section{English Translation}

\section{New Revised Standard Version}

1. Now the LORD said to Abram, "Go from your country and your kindred and your father's house to the land that I will show you.

2. I will make of you a great nation, and I will bless you, and make your name great, so that you will be a blessing.

3. I will bless those who bless you, and the one who curses you I will curse; and in you all the families of the earth shall be blessed."

4. So Abram went, as the LORD had told him; and Lot went with him. Abram was seventy-five years old when he departed from Haran.

5. Abram took his wife Sarai and his brother's son Lot, and all the possessions that they had gathered, and the persons whom they had acquired in Haran; and they set forth to go to the land of Canaan. When they had come to the land of Canaan,

6. Abram passed through the land to the place at Shechem, to the oak of Moreh. At that time the Canaanites were in the land.

7. Then the LORD appeared to Abram, and said, "To your offspring I will give this land." So he built there an altar to the LORD, who had appeared to him.

8. From there he moved on to the hill country on the east of Bethel, and pitched his tent, with Bethel on the west and $\mathrm{Ai}$ on the east; and there he built an altar to the LORD and invoked the name of the LORD.

9. And Abram journeyed on by stages toward the Negeb.

\section{Exegetical Study of the Text}

Without exegesis, the wealth of knowledge preserved in the sacred scripture will not be unveiled for adequate public consumption. Pontifical Biblical Commission avers that 'in order to interpret the Scripture with scholarly accuracy and precision, theologians need the work of exegetes. [2] Though exegesis can be applied to other texts other than the Scripture, this paper restricts it to study of the biblical text only.

\section{Structure of the Text}

For better understanding and appreciation of the text, the researcher broke the text into smaller units otherwise called structure of the text. The text is divided into 5 units, thus: The first section v1 gives account of the LORD's imperative to Abram to relinquish his ancestral heritage for an unknown land. This part can be captioned the command to leave. The second segment vv2-3 brought to focus the blessings of submitting to the LORD's command. The title of this section is benefits of obedience. The third part vv4-6 accounts the extent to which Abram submitted to the command given to him by the LORD. It is appropriate to call this segment submission to the command. The fourth division v7 pinpoints the conspicuous presence of the LORD with Abram. It is called confirmation of the LORD's presence. The last unit vv8-9 shows Abram's demonstration of worship to the Supreme Lord as sign of acknowledgement of his divine presence. This worship is culminated by the building of $n$ altar to the LORD. The title of this unit is evidence of worship.

\section{Close Reading of the Text}

The text will be explained taking into consideration the Hebrew words for better understanding.

\subsection{Vv1: The Command to Leave}

Studying vv1 critically, one would observe that it is obvious that Abram obtained favour from God. Generally, every human has one peculiar weakness or the other. This implies that no one is perfect and Abram is not excluded; perhaps he would not be the only man eligible to be chosen by the LORD or he might not be eligible at all to be chosen by the LORD but the LORD decided to choose him among others. Substantiating this thesis, Henry notes that God made choice of Abram and singled him out from among his fellow-idolaters that he might reserve a people for Himself, among whom his true worship might be maintained till the 
coming of Christ.[3]

The Hebrew phrase hw"hy> rm,aYOÝw: vayyö ${ }^{\circ}$ mer yhwh ('ädönäi) translated "Now the LORD said" indicates command from a higher authority. The subsequent statement "go..." confirms it. hw"hy> yhwh ('ädönäi) is a proper name of one supreme Lord which is unpronounced except with the vowel pointing; translation of the word to "LORD”(all in capital letters) depicts its special usage as supreme Being, hence LORD of the universe as against !wOda ädön meaning "ordinary lord" or "master" which is often used for human beings. rm,aYOÝw: vayyö ${ }^{\circ}$ 'mer "and he said" is better interpreted as command instead of said as used in the text.

$\wedge \pm 1 .-\%$ l lek-lükä 'go out' is Hebrew verb, qal imperative, masculine singular with participle preposition suffix, 2nd person masculine singular. The usage indicates that the supreme authority (LORD) issued a command to the subject (Abram). Abram therefore is under a highest force that he cannot disobey. It is pertinent to recall that the LORD has not commanded Abram to depart to another place in order to disorganize him. On this note Brown et al (eds) comment that the movement of Abram is not through Yahweh's scattering them but from a direct call to go to a land that He will show him.[4] It is therefore worthy of note to infer that the command for Abram to leave native home does not imply losing his identity as a Hebrew but the LORD desires to use him to form a new religion and nation for posterity. While making his contribution, Hartley avers that the imperative lek-lükä "go out" uses the play on sounds to underscore its urgency.[5] Folland maintains that the repetition of the preposition !mi min meaning "from" focuses attention on the three things Abram is to leave behind. The list progresses from the general "your land," to "your country," then to the specific "your father's house”.[6]

The word for kindred td,l,Am mô|lüdüt comes from the root dl;y" yäläd "he bore" and suggests birth or origin. According to Harris, Archer and Waltke, it is best understood as referring to Abram's blood relatives, to his tribe or clan. It does not refer to Abram's birth place as much as his tribal community.[7]

The positive aspect of the LORD's command was then described to Abram after spelling out what he was to leave behind. The relative clause \&'a<)r $>a$; $r \mathrm{rv}<\mathrm{ia} a] \# \mathrm{r}<\mathrm{a}$ ' $\mathrm{bh}$ hä'äorec 'ášer 'ar' ${ }^{0} \mathrm{KKä} \mathrm{translated} \mathrm{"the} \mathrm{land} \mathrm{that} \mathrm{I} \mathrm{will}$ show you" describe Abram's destination. It was not Abram's idea to leave nor did he have any destination in mind. The LORD who issued the command would reveal the destination. This also shows that it is the LORD who maintains the initiative throughout.

\subsection{Vv2-3: The Benefits of Obedience}

Three promises abound for Abram for obeying the LORD: the first, He will make him a great nation, second, He will bless him and thirdly, He will make his name great.
The term yAG gôy "nation” according to Harris, Archer and Waltke is used especially to refer to specifically political, ethnic or territorial groups of people without intending to ascribe to a specific religious or moral connotation.[7] The LORD's second promise is that he will bless Abram. Murtonen posits that it introduces a theme of "blessing" Büräkâ that runs throughout the Patriarchal narratives. Its meaning appears, in this instance, quite general.[8]

An accurate understanding of בדּרָּ Bäräk is crucial to understanding the whole call of Abram.

Harris, Archer \& Waltke continue to assert that this root and its derivatives occur 415 times. The majority are in the Piel stem (214) which is translated 'to bless.' The Qal passive participle 'blessed' occurs sixty-one times”.[7]

The Qal passive participle can be used of God (e.g. Gen. 9:26, 24:27), of a person (e.g. Gen 27:33) or of things (e.g. Deut 28:4). It also appears in the Niphil perfect consecutive only in v.3 of our passage (see below), and the subsequent iterations of the promise in Gen 18:18 and 28:14.

In the Piel it appears 50 times in the perfect (e.g. Gen 24:1) where the subject has blessed the object. It occurs 122 times in the imperfect (e.g. Gen 12:3), where the subject promises to bless the object in the future. It occurs 30 times in the imperative, as a command or request for a blessing to be bestowed. It occurs 30 times as an infinitive construct (e.g. Gen 22:17).

Despite its many occurrences, determining the meaning of the verb is made more difficult because it appears to produce no immediate tangible outcome.

What does it mean when God is the subject of the verb? Mitchell writes,

"...the factor that makes a blessing a blessing is the relationship between God and the person blessed. God blesses because of his 'favourable' attitude toward a person or group of people.[9] Hillmer avers that a blessing is any benefit or utterance which God freely bestows in order to make known to the recipient and to others that he is 'favourably' deposed toward the recipient."[10]

Buttressing further on Abraham's blessing Carrol traces that in Genesis 1:22, God blessed the creatures in the water and the birds of the air with the words, "Be fruitful and increase in number...." He also blessed human beings (1:28) with the same words, and added "fill the earth and subdue it”. Therefore, blessing seems clearly to involve fertility and, for human beings, effectively carrying out their divinely appointed role as stewards of the earth. Of course, both of these aspects were impacted by the curse in Genesis 3, where childbirth becomes painful and the work becomes toil. Blessing also includes material prosperity. In Genesis 24:1 God's promise to Abraham is explicitly said to have been fulfilled. Abraham has been blessed. In Genesis 24:35, Abraham's servant describes how he has been blessed. He has become great, acquired many material possessions, and has a son.[11] Surely the blessing of God includes fertility, prosperity and success. It is the same 
blessing that led to conversion of his name from Abram to Abraham meaning father of all nations.

What does it mean for one person to bless another? Often a blessing was given at a time of departure, especially when death was imminent. The most extensive example of this comes from Genesis 27, where Isaac blesses his son, Jacob. Murtonen argues that the patriarch's soul is translated to the heir, with the understanding that the recipient is to do everything in his ability to realize the blessing that has been given.[8] Preferable, though, is Mitchell's argument that this practice is the equivalent of a legal last will and testament, rather than anything magical Hillmer. By blessing his heir, the patriarch is helping trace the line of the promised seed (Gen 3:15).[10] Spence-Jones opines that the blessing was a recompense for the deprivations entailed upon him by forsaking the place of his birth and kindred.[12]

The third promise 'to make Abram's name great' means that Abram does not need to seek or strive to gain fame because God graciously offers to give him "great" name. By these promises, Abram stood to lose nothing for submitting to the LORD's command.

Having discussed the first chain of the LORD's promises to Abram, the next two include the LORD's promises to bless those who bless Abram and curse those who curse him. There is a notable textual problem in the English translation with special reference to the use of the first curse and the second curse as indicated in the text. Though the two different words are translated as curse in English version, their meaning and usage vary. The Hebrew text from Elliger \& Rudolph eds write, thus Wkår $>$ b.nIw $>$ rao=a' ^ßl.L,q;m.W ûmüqallelkä 'ä’ör vünibrükû meaning "and the one who curses you I will curse." The first clause "one who curses you." [13] Curses is Hebrew qal perfect ' ll;q' qäläl, germinate root, 3rd person masculine singular meaning to be slight, swift or trifling. The usage suggests "to treat with contempt", "to despise", or "to oppose". The second clause "I will curse." Curses is traced to Hebrew qal perfect rr;a" 'ärär which is also germinate root, 3rd person masculine singular meaning to curse, or to revile. It represents condemnation, deprivation of blessing or being utterly accursed. It is this understanding that Folland presents thus "God will deal with those who oppose Abraham, just as he rewards those who bless him. This second chain of promise according to him is a promise of God's providential protection.[6] Henry and Scott contend that God will take care that none is a loser by any service done for his people.[14]

hm'(d"a]h' txoïP.v.mi lKoß ^êb. bükä Köl mišPüHöt hä ádämâ "...in you all the families of the earth shall be blessed," can be understood as a passive, reflexive or middle voice. Towner provides the three alternatives for this phrase, thus:

1. "in you all the families of the earth will be blessed (passive)

2. "in you all the families of the earth will bless themselves (reflexive)
3. "in you all the families of the earth will find a blessing (middle)[15]

The passive which NRSV translated is preferred according to Matthew who in his words argues thus, "it probably suits the context of the passage best since God is the source and Abram in our analysis is the channel.[16] The usage txoïP.v.mi lKoß Köl mišPüHöt meaning "all the families" signifies that every clan irrespective of culture, background, nation, history, language, religion share common patrimony of Abram's blessing. Highlighting this point, Smith comments that Abraham who is already made a blessing is now source of blessing for the universe. Indeed, no tribe of the earth is exempted from the blessing. All are included.[17]

\subsection{Vv4-6: Submission to the Command}

Abram's action speaks louder than voice; without any interrogation, he went as he was commanded. This illustrates his complete trust and obedience to the LORD who called him. His noble character here is a typical demonstration of his personal determination. Mcgee concurs to this idea by adding that the mark of a great man is that he must be noble of character, a generous man.[18] The age of Abraham can be discussed in two ways in this context.

1 According to Deffinbang 'Abram's age was not a factor of leaving Ur for an unknown land either. We are not inclined to be impressed with Abram's age because of the length of man's life in the olden times.'[19] The information in Genesis 11 confirms that man's longevity was much greater or longer in times past than in Abram's day. Butressing further, if Abram's age is to be compared with his forebears then he is a young man at 75 .

2 In the words of Bratcher, part of significance of Abram's age is that at 75 he was getting along in years, it was not the time in life to start planning families and looking for a new future to unfold let alone begin thinking about building a great nation.[20] In addition to the view above, Abram should have firmly settled in his ancestral home land; but at 75 , he began an incredible journey. So, the age of Abram is a manifestation of faith, genuine submission to LORD as well as self-denial.

The second action taken by Abram is taking with him, his wife, Sarai, his nephew, Lot, and all their possession. v'Wkr>-lK' Kol-rükûšäm translated "all possessions." $\mathrm{v}^{\prime} \mathrm{W} k r$ rükûš is masculine singular noun absolute. It means property, goods or possession. It is a general term for all moveable property or goods. It is used in the text to designate all moveable property of Abram including livestock, hired servants, utensils etc.

At the time that Abram arrived at Canaan and passed through the land of Shechem, the Canaanites were still in the land. Shechem is very significant in the study because it is a place which was identified as a place of worship by the mention of hr<_Am !Alåa 'ëlôn môrè “Oak of Moreh.” 
Substantiating this point, Campbell observes that the name of the tree suggests that this was a place of worship among the Canaanites.[21]

It is obvious that Abram was a wealthy man but he did not make his wealth an idol or allow it to become hindrance to his relationship with God. Wiersbe confirms this thesis thus, "it is easy to see that Abraham was a wealthy man but that his wealth was no barrier to his walk with God.”[22]

\subsection{Vv7: Confirmation of the LORD's Presence}

For the LORD to appear to Abram x-rays that the LORD Himself is involved in the mission He sent Abram. It is a sign of His presence with him. The LORD uses the appearance of His presence to encourage Abram and prove to him that He has not deserted him. The Hebrew meaning of the word "appeared" which is ar"ÛYEw vayyërä' in the text shows that the LORD come to inspect the project he gave Abram. According to Greidanus, the Lord gives Abram the land of Canaan for possession.[23] Moreso, the claim of the land of Canaan by Abram is continuous manifestation of his blessing as the LORD's chosen. The land is possessed by Abram's generation, hence the use of [r;z< zerä ' "offspring” in the text. Abram's action which was demonstrated in the building of the altar implies acceptance /recognition of the LORD's presence through worship. It equally denotes immediate claim of ownership of the land. The word \#r<a'äh hä'ärec "the earth" which means in the context of this study, "whole earth" as opposed to "part of the earth" shows that the LORD has given Abram the whole earth as possession/inheritance and his subsequent generations are automatically heirs of the inheritance.

\subsection{Vv8-9: Evidence of Worship}

The narrator continues to record Abram's movement. Folland highlights that Abram again built a second altar and called on the name of the LORD. Building of altar(s) is a description of evidence of worship which is characterized by direct personal encounter with God.[6] He went further to argue thus "....although there is little direct evidence describing the details of patriarchal worship, it was characterized by direct personal encounters with God often memorialized by the construction of altars, at significant locations within the land, on which the patriarchs presented sacrifices to the Lord directly, without the benefit of an intermediary. This brief characterization suggests that the particular name for God which Abram used here is less relevant than the fact that he has responded to two direct personal encounters with the Lord. Abram did not just obey, he worshipped."'[6]

The phrase hl\{+hไa' jYEåw: vayyë† 'ohólò “and he pitched his tent," signifies that Abram already had a home in the land. But it is necessary to note that lh,a 'öhel "tent" is a symbolic of wilderness life which is transient. Abram built a nomadic home probably for a temporal habitation because Bethel is not his final destination; his journey is still ahead. The word hj'n" nätäh "pitched" informs us that the tent was extended having being in existence.

The building of the second altar strengthens the claim of ownership of the land where he sojourned. It is this view that Edersheim put in his words thus, "Abraham continues his journey, going on still towards the South, a pilgrim and a stranger in the land of promise, his possession of it only marked by the altars which he left on the track." [24] The erection of altars is a symbol of act of thanksgiving to the LORD for successful arrival. Carson et al sums up this idea as follows: "God's gracious promise prompted Abram to repeated acts of thankful worship."[25]

\section{Application of the Text in the Contemporary Society}

The first verse of Gen 12 implies that Abram obtained favour from the LORD; it is unquestionable that call to the office of a priest is an unmerited favour from God. Those who are called to such sacred post are not called as a result of their eligibility. They must without hesitation respond to this great privilege with humility and diligence. Ngele comments on this when he avers that, 'as leaders in socio-ecclessia positions--- we must denounce pride, selfishness, greed, and embrace love and humility in the manner of Christ.' [26] One does not receive God's grace in vain. The favour God gives to people requires responsibilities. In other words favour of God is expected to be followed by productive responsibilities. Agha and Nwaoga intone that 'responsibility is the quality or state of being responsible for all acts of thought and conduct. It is a state of being responsible as a moral, legal or mental accountability.'[27] The notable aim of becoming a priest is to discover divine purpose and achieve it.

Abram was given a command to depart for the LORD's known destination. Theologically, he went because God issued him ultimatum to undertake the mission, not because he had no occupation as it is with some priests of our contemporary. It is therefore kaput to take office of a priest as alternative to employment. In respect to this, Ituma observes that 'dropout and uneducated are now becoming preachers and pastors... whosoever hits hard luck in business sees it as a call to the ministry. God wants him to go into the ministry.'[28]

Moreover, material and human possessions of Abram shows that before he had the call of the LORD, he was already a very wealthy man. His obeisance to the divine imperative was not a means of acquiring wealth. Christian priests are left with moral reflections in this regard. Today, many priests jump into ministry with sole aim of acquiring material wealth. Their sermon which places more emphasis on material prosperity than prosperity of the soul and their attitude of greed and avarice towards wealth make this 
claim a reality. Such is the kind of priests we see in the recent time. What an irony! Lamido succinctly describes such priests as follows, professional pastors. They are pastors for financial gain. They are interested in what they can get from the flock. They contrive for their own ease, advantage and honour. Some of them 'prophesize' (sick) in order to obtain some financial favour from the people.[29]

The use of rükûš 'possessions' which Abram carried alongside his wife and nephew is moveable property probably for family use, and this suggests Abram's contentment. This lifestyle of contentment is far removed from some priests in the contemporary time. Some of them are so greedy that they monopolise denomination and convert church property to private ownership. Today members of some denominations are levied for one project or the other. Sometimes, funds realised for such projects are converted for personal use and selfish interest.

Abram moved from Canaan, passed through Shechem, moved to Bethel and to Negeb. He built altars of worship, pitched tents and called on the name of the LORD. All these speak for him as a man of uprightness and industry. He sought God's presence and acknowledged Him. But the reverse is the case among many Christian priests today. The way and manner these priests bribe their way to acquire certain positions in the church, and to be posted to church with large population of members and those in the urban areas is an eloquent expression of their wrong motives for delving into priesthood. The similar attitude to this concerns itself with their unwillingness or reluctance to accept posting to remote rural areas as if people in the rural areas do not need salvation. This intones that they joined ministry to worship mammon instead of God. Ugwu uses Anglican church as an example to validate this fact thus 'Taking the Anglican church as an example, we find an undeniable expression of serious politicking among some priests when a new diocese is about to be created and or when a bishop is about to retire... this is purely coming from 'their' ulterior motive such people had while joining the priesthood.[1]

Priests who are oracles of God (prophets) are expected to proclaim the mind of God both in words and deeds as Abram demonstrated throughout the narrative. Ejenobo is of the view that prophets 'went' from place to place proclaiming the message of God.[30] It is apparent that Abram sojourned to many places and demonstrated the message of God. But some contemporary priests go from place to place for some political interest and other monetary based interest instead of to represent the LORD who called them. Even when they set for the gospel in various places, it has become custom that they must give a cash envelope. It seems an irrevocable custom in some denominations that a priest who served in the altar on Sunday service is entitled to a token which may be referred to as altar allowance. Any lay leader of the church who opposes or questions such has become enemy of progress and oppose of God's minister. This silly attitude extends to prayer for God's blessings. Members of the congregation receive so called special prayer for divine favour and blessings in proportion to their financial capacity and support to so called God's work. Is the blessing of God an article of trade? What an abuse of Christian priesthood and mockery of Christian faith.

Another interesting aspect of this study finds itself in Abram's source of blessing to all the families of the earth. It is in him that every tribe must be endowed with the LORD's blessing; Abram's lifestyle in the subsequent passage proves it. In our contemporary, it is a direct opposite of what members of the church encounter from some priests. They are today source of burden to their members. Year after year church members are levied in addition to payment of tithe and offering, and incessant fund raising as well as seed sowing. In some denominations, any deceased member who, peradventure, did not complete his or her levy may not be formally paid homage to and or be buried in accordance with the church tradition and liturgy. What a menace! It is now compulsory in some churches that besides priests' salary/stipend, it is core responsibilities of church members to provide accommodation, feeding, car and other required provisions for their priest. Though it may not be bad for members of the congregation to take care of their priest, but their unsatisfaction and poor or lack of appreciation often demonstrated by some of them make it cruel and greedy.

Some of these priests are hypocrites who preach virtues but practice vices. They demonstrate on daily basis opposite of what they preach. They lure some of their members into fornication, adultery, falsehood etc. Some join cultic group for extra-ordinary power to perform miracles. Some compare themselves with secular leaders and desire to become like them. The selfless life which they ought to be known for is now odd. The life of pilgrimage which Abram was known for is neither cherished nor emulated by contemporary Christian priests. Christian priests have carelessly and ignorantly forgotten that the world is not a permanent place for man.

\section{Conclusions}

The text of this study teaches us that Abram demonstrated lifestyle worthy of emulation by Christian priests. His eagerness to sojourn to different places such as Canaan, Shechem, Bethel and Negeb passes an undeniable message of total obedience and submission to divine call. His building of altars and pitching of tent illustrate worship of God and pilgrimage life on earth. This Abram's pattern of response to divine call left our priests with moral reflections. The ulterior motives of some priests in joining priesthood as discussed in this monograph express the sorry situation of Christian priesthood in the modern time. There is indeed urgent need for positive response.

The results of ill-attitude found among Christian priest 
include immorality in the church, heavy burden upon members, bribery and corruption within ecclesiology, non-imparting sermon, politics in the church, syncretism etc. There is immediate need for priests to reflect on the pattern of life adopted by Abram when he positively responded to divine call.

\section{REFERENCES}

[1] Ugwu, C. I (2011); Biblical Moses: A Model for Contemporary Christian Priests. International Journal of Theology and Reformed Tradition vol 3. Nsukka: Society for Reseach and Academic Excellence.

[2] Pontifical Biblical Commission (1993); The Interpretation of the Bible in the Church. Rome: Liberia Editrice Vaticana.

[3] Henry, M (1991); Matthew Henry's Commentary on the whole Bilble: Complete and Unabridged in one volume. Peabody: Hendrickson.

[4] Brown, R. E et al (eds) (1968); The Jerome Biblical Commentary. New Delhi: Indira Printers.

[5] Hartley, J. E. (2000); Genesis. Peabody, Massachusetts: Hendrickson Publishers:

[6] Folland, G (2009); Exegesis Paper on the Hebrew Text of Genesis 12:1-9. Geofffolland Wordpress.com weblog.

[7] Harris, R. L., Harris, R. L., Archer, G. L., \& Waltke, B. K. (1999); Theological Wordbook of the Old Testament (electronic ed.) Chicago: Moody Press.

[8] Murtonen, A (1959) "Use and meaning of the words lebarek and berakah in the Old Testament.” Vetus Testamentum 9 no 2 Apr, p 158-177.

[9] Mitchell, C. W (1987); “The Meaning of BRK 'To Bless' in the Old Testament Atlanta, GA: Scholars Press.

[10] Carroll, M. D (2000); "Blessing the Nations: Toward a Biblical Theology of Mission from Genesis” Bulletin for Biblical Research.10.1.

[11] Spence-Jones, H.D. M (2004); The Pulpit Commentary: Genesis. Bellingham W.A: Logos Research System Inc.

[12] Elliger, K \& Rudolph, W (1967); Biblia Hebraica Stuttgartensia. Geramany: Deutsche Bibelgesellschaft, Stuttgart.

[13] Henry, M \& Scott, T (1997); Matthew Henry’s Concise Commentary. Oak Habor, W.A: Logos Research System.

[14] Towner, W. S (2001); Genesis. Louisville, Kentucky: Westminster John Know Press

[15] Mathews, K. A (2005); Genesis 11:27-50:26. New American Commentary. Nashville, Tennessee: Broadman \& Holman Publishers.

[16] Smith, J.E (1992); Old Testament Survey Series: The Pentateuch. Joplin Missouri: College Press Publishing Company.
[17] Mcgee, J. V (1981); Thru the Bible Commentary. Electroniced. Nashville.

[18] Deffinbaugh, B (2004); Genesis: From paradise to patriarchs. http://bible.org/seriespae/call-abram-genesis.

[19] Bratcher, D (2013); Literary and Theological Setting of the Text (Gen 12:1-9). http://www.crivioce.org>lectionaryRes ources $<$ years.

[20] Campbell E. F (1985); “Moreh” in Achtemeier. Harper's Bible Dictionary $\left(1^{\text {st }}\right.$ ed). San Francisco: Harper \& Row.

[21] Wiersbe, W.W (1993); Wiersbes Exposition Outlines on the Old Testament. Bay City, USA: A division of Scripture Press Publications Inc.

[22] Greidanus, S (2008) "Detecting Plot Lines: The Key to Preaching the Genesis Narratives" Calvin Theological Journal vol 43.

[23] Edersheim, A (1876); Bible History Old Testament. Michigan: William B Ergman Pulblishing Company.

[24] Carson, D. A et al (1953); New Bible Commentary $21^{\text {st }}$ Century Edition. Leicester England: Intervarsity Press.

[25] Ngele, O.K (2009); 'Exegesis of john 13: 1-17: Implication of Jesus' Servant Leadership model for the Church and Nigerian Society.' Nsukka Journal of Religion and Cultural Studies vol. 4, no1. Enugu: Pross-Prints and Communications.

[26] Agha, U \& Nwaoga, C (2012); Nigeria, A Nation in Search of Peace as the Panacea. Nsukka Journal of Religion and Cultural Studies, vol. 5. Enugu: Timex.

[27] Ituma, E. A (2000); Clergy on Strike. Lagos: Chinedum Publishers Ltd.

[28] Lamido, A. B (2007); Becoming a Pastor of the Church: The example of the Fulani Herdsman. Zaria: Tamaza Publishing Company Ltd.

[29] Ejenobo, D. T (2009); Christian Religion Leaders as Agents of National Development in Nigeria. Arts and Social Sciences Research Journal vol1. Nsukka: Global Publishers Nigeria. 